УДК 686.12.056

\title{
ПРИСТРІЙ ДЛЯ БЕЗУПИННОГО ОБРІЗУВАННЯ АРКУШЕВОГО МАТЕРІАЛУ В ПОТОКОВИХ ЛІНІЯХ
}

\author{
() А. І. Іванко, К.т.н, доцент, Р. В. Маржієвський, магістрант, \\ НТУУ «КПІ», Київ, Україна \\ В статье рассмотрена новая конструкция устройства \\ безвыстойной обрезки листового материала в поточных \\ линиях.
}

In the article is described the new construction of device of the nonstop trimming of sheet material is considered in production lines.

\section{Постановка проблеми}

Потокові лінії суттєво підвищують продуктивність роботи за рахунок безупинного обрізування аркушевої продукції. Проектування пристроїв, що технологічно забезпечували б зрізування головки, передка та корінця аркушевого матеріалу під час його переміщення у транспортувальному пристрої вимагають значних аналітичних та експериментальних досліджень.

\section{Аналіз попередніх досліджень}

Відомі конструкції механізмів для обрізування аркушевої продукції де для приводу ножів застосовують механізми періодичного повороту у вигляді неповнозубих коліс з епіциклоїдним пристроєм. Він застосовується для введення зубчастих коліс в зачеплення і виведення їх із зачеплення. Механізми періодичного повороту складніші по конструкції, зате забезпечують тривалу стабільну роботу ножів, надійність їх дії і постійність вихідного положення [1, 2]. Не- доліком даних механізмів $\epsilon$ погіршення їх роботи при спрацюванні виконавчих елементів.

Шаблевидний рух ножа, що використовується у різальному верстаті [3], реалізується за допомогою підвіски на двох тягах або за рахунок переміщення ножетримача з двома пазами, що мають різні кути нахилу та по сухарях, закріплених на осях в корпусі верстата.

\section{Мета роботи}

Метою даної роботи є підвищення продуктивності роботи потокової лінії та якості обрізаного корінця напівфабрикату, зниження потужності споживання приводу в цілому за рахунок запропонованої конструкції пристрою. Забезпечити зменшення часу на технологічний процес різання і транспортування матеріалу за рахунок безупинного технологічного процесу - одночасного виконання операції його фіксування та послідовного обрізування. Об'єктом досліджень є нова схема пристрою для обрізування і транспортування напівфабрикату безупин- 
ним способом, що вміщує в собі кривошипно-кулісний привод.

\section{Результати проведених досліджень}

Пропонується новий спосіб безупинного обрізування аркушевого матеріалу та пристрій для його реалізації. Пристрій складається з транспортувальної системи, механізму притиску та механізму ножа (рис. 1).

Транспортувальна система отримує рух від головного привода. До її складу входять накладні столи, на кожному з яких може переміщуватися в різальну секцію напівфабрикат. Напівфабрикат попереднім притиском фіксується на накладному столі і передається в зону обрізування. Жорсткість горизонтального руху стола разом із блоком забезпечується двома напрямними (на рисунку не показано).

Пристрій працює наступним чином (рис. 1). Книжковий блок після вирівнювання попереднім притиском затискається в каретці. Дія головного притиску і різання блоку відбувається під час транспортування. Головний притиск і ніж закріплені на горизонтальній рамі, яка обертається на кривошипах. Коли рама підходить в крайнє нижнє положення починає діяти головний притиск. Необхідне зусилля притиску забезпечується притискними пружинами і регулюється гідравлічними циліндрами прикріпленими до рами. Чим нижче буде опускатись рама тим більше буде зусилля притиску. Це дає змогу виконувати процес різання під час одночасного руху каретки з блоком.

У приводі притискної балки залежність $\alpha / \beta$ дорівнює відношенню часу прямого ходу до часу зворотного ходу. В кривошипно-кулісному механізмі рух ножа забезпечується за рахунок обертання ножетримача 13 ножем 2 навколо осі $\mathrm{O}_{2}$, а ножетри-

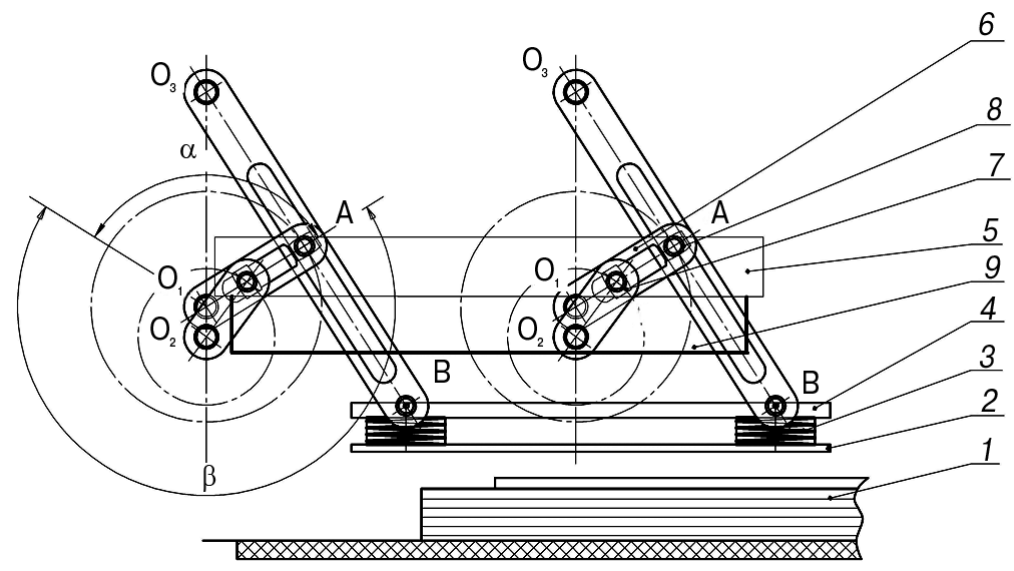

Рис. 1. Спосіб безупинного обрізування аркушевого матеріалу та пристрій для його реалізації: 1 - книжковий блок; 2 - головний притиск; 3 - пружина; 4 - рама притиску; 5 - ножетримач; 6 - куліса; 7, 8 - кулісний камінь 
мач закріплений в повзуні 3. Коли кривошип підходить до нижнього положення відбувається різ, під час різу сила притиску не постійна і змінюється під час розрізання напівфабрикату (рис. 2).

Для попереднього кінематичного розрахунку механізму, визначення сил, що діють на виконавчі ланки та реакцій в кінематичних парах скористаємось характерними геометричними розмірами виконавчих ланок: $\mathrm{L}_{\mathrm{O} 1 \mathrm{C}} ; \mathrm{L}_{\mathrm{O} 2 \mathrm{~A}} ; \mathrm{L}_{\mathrm{O} 3 \mathrm{~B}} ; \mathrm{L}_{\mathrm{O} 102} ; \mathrm{L}_{\mathrm{O} 2 \mathrm{O} 3}$. Ніж 3 ножетримачем закріплені в кулісному камені, точки A, а рама притиску закріплена в точках В.

Силові процеси, що відбуваються у механізмі відбуваються за принципом Д'Аламбера: якщо до системи окрім сил активних додати сили інерції, то в умовах перехідних процесів можна вважати, що сума сил дорівнює нулю, а багатокутник сил, побудований для неї, буде замкнений.

Для аналізу динамічної схеми механізму враховуємо: сили тяжіння $\mathrm{G}=\mathrm{m} \cdot \mathrm{g}$; моменти інерції $\mathrm{J}=\mathrm{m} \cdot \mathrm{I} / 3$; сили інерції $\mathrm{P}=\mathrm{m} \cdot \mathrm{a}$; та моменти сил інерції $\mathrm{M}=\mathrm{J} \cdot \varepsilon$.

В подальших розрахунках слід визначити зусилля різання $F_{\mathrm{p}}$ та притиску $F_{\text {пр }}$. Так як маси ланок відносно не великі то можна припустити, що вони не матимуть визначального впливу у подальших розрахунках.

Знаючи навантаження, що впливають на механізм, знаходимо необхідні реакції та зрівноважуючу силу, враховуючи при цьому висоту різу $\mathrm{h}=15 \mathrm{mм}$; частоту обертання кривошипа $\mathrm{n}=240$ хв$^{-1}$; кут по-

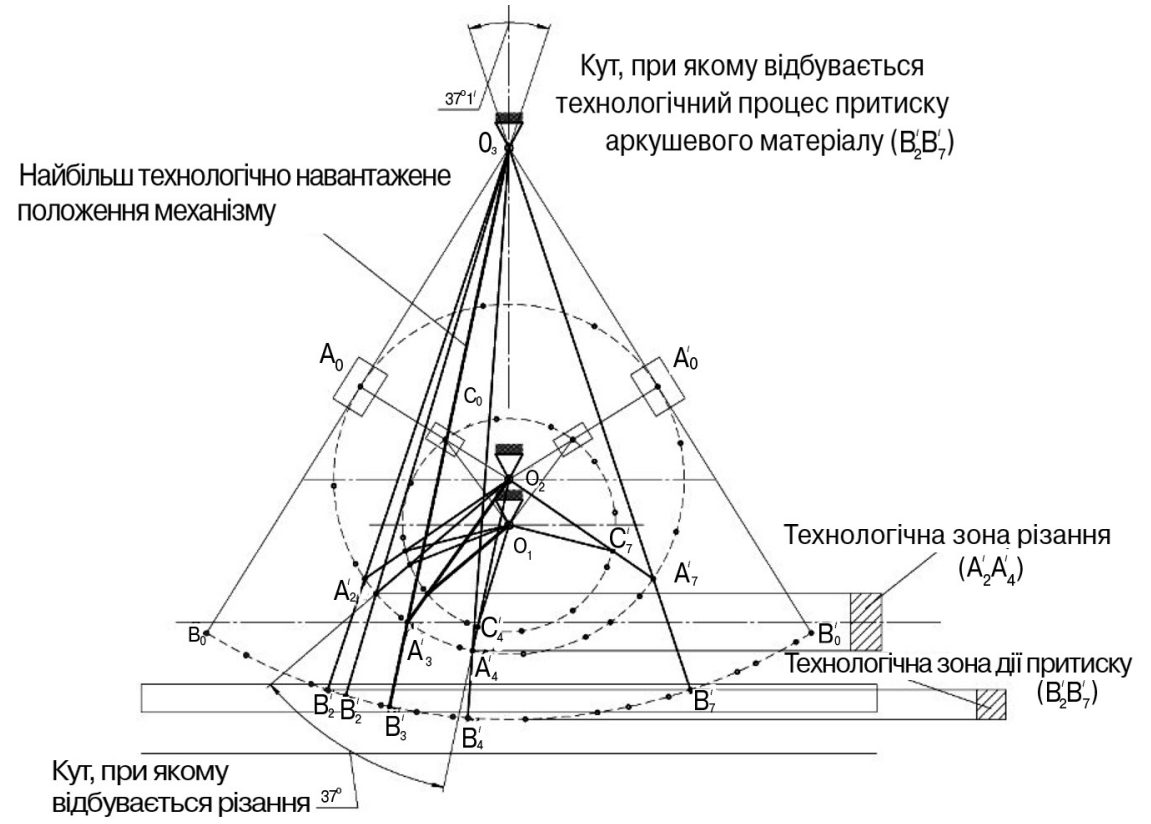
$\left(A_{2}^{\prime} A_{4}^{\prime}\right)$

Рис. 2. Кінематична схема характерних кутів повороту виконавчих ланок для визначених положень механізму 
вороту ланки 4, при якому відбувається різ $\alpha$.

Визначимо час протягом якого відбувається обрізування $\mathrm{t}=\frac{60}{2 \cdot \pi \cdot \mathrm{n}} \cdot \alpha$ та роботу, що затрачається за один оберт кривошипа $A=\frac{F \cdot L_{4} \cdot \alpha}{1000}\left(\right.$ при $L_{4}=28$ мм $)$.

Потужність, що приведена до одного оберту кривошипа $\mathrm{P}_{\mathrm{k}}=\frac{A}{60} \cdot \mathrm{n}$. Відповідно ККД механізму для пар обертання $\eta_{1}=0,98 ;$ поступальних пар $\eta_{2}=0,96$ та редуктора $\eta_{3}=0,85$. Загальний ККД механізму $\eta=\eta_{1}^{6} \cdot \eta_{2}^{2} \cdot \eta_{3}$. Потрібна потужність двигуна $\mathrm{P}_{\mathrm{n}}=\mathrm{P}_{\mathrm{k}} / \eta$ та крутний момент на кривошипі $\mathrm{T}=\frac{\mathrm{P}_{\mathrm{k}} \cdot 30}{\pi \cdot \eta}$.
Скориставшись результатами розрахунків можна підібрати двигун необхідної потужності. Наприклад двигун типу АИР71B2P3.

\section{Висновки}

Запропонований спосіб беззупинного обрізування під час транспортування напівфабрикату пристрій для його реалізації, дозволить суттєво покращити швидкісні показники потокового виробництва книжкової продукції, скоротити час на переналагодження різальної секції та частково спростити конструкцію пристрою.

Дана конструкція пристрою після подальших аналітичних досліджень може бути рекомендована для подальших експериментальних досліджень.

1. Хведчин Ю. Й. Брошурувально-палітурне устаткування. Ч. 1. Брошурувальне устаткування. Підручник / Ю. Й. Хведчин. - Львів : ТеРус, 1999. - 336 с. 2. Пергамент Д. А. Брошюровочно-переплетное оборудование / Д. А. Пергамент. - М. : МПИ, 1990. - 452 с. З. Звіт по НДР. Розробка науково-технічних основ структури побудови та проектування віброножових паперорізальних машин. - № 2753. - К. : НТУУ «КПІ», № державної реєстрації 0104U003143, 2006 р. - 64 с. 4. Топольницький П. В. Нові технології та пристрої для різання поліграфічних матеріалів та книжково-журнальних блоків : навч. посіб. / П. В. Топольницький, О. Б. Книш. - Львів : Афіша, 2003. - 88 с. 5. Іванко А. І. Механіка процесу обрізування книжково-журнальних блоків дисковими ножами 3 планетарним приводом : дис. ... канд. техн. наук : 05.05.01 / Іванко Андрій Іванович. - Київ, 2007. - 181 с. 6. Гречко Л. П. Синтез механізмів і динаміка машин : навч. посіб. / Л. П. Гречко. - Харків, 1998. - 207 с. 7. Гречко Л. П. Рычажные механизмы, передачи и зацепления : учебное пособие / Л. П. Гречко. - Харьков, 2000. - 219 с. 8. Артоболевский И. И. Теория механизмов и машин : Учеб. для вузов. / И. И. Артоболевский. 4-е изд., перераб. и доп. - М. : Наука. Гл. ред. физ.-мат. лит., 1988. $640 \mathrm{c}$.

1. Khvedchyn lu. I. Broshuruvalno-paliturne ustatkuvannia. Ch. 1. Broshuruvalne ustatkuvannia. Pidruchnyk / lu. I. Khvedchyn. - Lviv : TeRus, 1999. - 336 c. 2. Pergament D. A. Broshjurovochno-perepletnoe oborudovanie / D. A. Pergament. - M. : MPI, 1990. - 452 s. 3. Topolnytskyi P. V. Novi tekhnolohii ta prystroi dlia rizannia polihrafichnykh materialiv ta knyzhkovo-zhur- 
nalnykh blokiv : navch. posib. / P. V. Topolnytskyi, O. B. Knysh. - Lviv : Afisha, 2003. - 88 s. 4. Ivanko A. I. Mekhanika protsesu obrizuvannia knyzhkovo-zhurnalnykh blokiv dyskovymy nozhamy z planetarnym pryvodom : dys. ... kand. tekhn. nauk : 05.05.01 / Ivanko Andrii Ivanovych. - Kyiv, 2007. - 181 s. 5. Hrechko L. P. Syntez mekhanizmiv i dynamika mashyn : navch. posib. / L. P. Hrechko. - Kharkiv : 1998. - 207 s. 6. Grechko L. P. Rychazhnye mehanizmy, peredachi i zaceplenija : uchebnoe posobie / L. P. Grechko. - Har'kov : 2000. -219 s. 7. Artobolevskij I. I. Teorija mehanizmov i mashin : ucheb. dlja vuzov. / I. I. Artobolevskij. - 4-e izd., pererab. i dop. - M. : Nauka. Gl. red. fiz.-mat. lit., 1988. $-640 \mathrm{~s}$.

Рецензент - С. Л. Панов, к.т.н., доцент, НТУУ «КПІ»

Надійшла до редакції 21.09.12 